\title{
A beacon of dung: using lemming (Lemmus lemmus) winter nests and DNA analysis of faeces to further understand predator-prey dynamics in Northern Sweden
}

\author{
Jan Vigués ${ }^{1} \cdot$ Silvia Menci $^{1} \cdot$ Caitlin Wilkinson $^{1} \cdot$ Maryline Le Vaillant $^{1} \cdot$ Anders Angerbjörn $^{1} \cdot$ Karin Norén $^{1}$ (B)
}

Received: 11 December 2020 / Revised: 6 October 2021 / Accepted: 19 October 2021 / Published online: 3 November 2021

(c) The Author(s) 2021

\begin{abstract}
The hypothesis that predation is the cause of the regular small rodent population oscillations observed in boreal and Arctic regions has long been debated. Within this hypothesis, it is proposed that the most likely predators to cause these destabilizing effects are sedentary specialists, with small mustelids being possible candidates. One such case would be the highly specialized least weasel (Mustela nivalis) driving the Norwegian lemming (Lemmus lemmus) cycle in Fennoscandia. These predators are often elusive and therefore distribution data can only be based on field signs, which is problematic when various mustelid species are sympatric, such as weasels and stoats (Mustela erminea). Here we present the results of using mustelid faeces in predated winter lemming nests to correctly identify the predator and thus discern which species exerts the strongest predation pressure on lemming winter populations. Samples were obtained during different phases in the lemming cycle, spanning 6 years, to account for different prey densities. Faecal mitochondrial DNA extraction and amplification of a 400-bp fragment was successful in $92 / 114$ samples (81\%); the sequencing of these samples proved that most predation occurrences $(83 \%)$ could be attributed to the least weasel. These findings support the hypothesis that weasels in particular show high specificity in predation and could therefore be candidates to driving the lemming cycle in this area. We conclude that DNA analysis of faecal remains around predated nests can be a useful tool for further investigations concerning predator-prey interactions in the tundra.
\end{abstract}

Keywords Mustelid $\cdot$ Norwegian lemming $\cdot$ Rodent cycles $\cdot$ Faecal DNA $\cdot$ Non-invasive genetic sampling

\section{Introduction}

The concept of predation as the causal factor in the observed regular oscillations of small mammal populations, especially in Arctic regions, has long been proposed in the research of the so-called "rodent cycle" (Elton 1924; Hanski et al. 1991, 2001; Andersson and Erlinge 1977; Sittler 1995; Legagneux et al. 2012; Krebs 2013; Hoset et al. 2014). Furthermore, the separation of predators into three different types: resident specialists, nomadic specialists and generalists (Andersson and Erlinge 1977) and their subsequent implications, have been established within the predator hypothesis (Hanski et al. 2001). One such implication is the destabilizing effect

Karin Norén

karin.noren@zoologi.su.se

1 Department of Zoology, Stockholm University, 10691 Stockholm, Sweden caused by sedentary specialist predators on rodent populations (Andersson and Erlinge 1977; Hanski et al. 1991; Reid et al. 1997). However, this hypothesis has been highly controversial in the study of the rodent cycle (Graham and Lambin 2002), with many other authors proposing food availability (Krebs 2011), parasites (Forbes et al. 2014), stress (Boonstra and Boag 1992) or a combination of factors (Turchin et al. 2000; Fauteux et al. 2016) as being the causes of cyclicity (Andreassen et al. 2021).

Nevertheless, due to their specialist and sedentary nature, small mustelids have been suggested as possible drivers of the rodent cycle (Hanski et al. 2001; Gilg et al. 2003; Ekerholm et al. 2004). In the case of the Fennoscandian tundra, two species of mustelid are sympatric; the stoat (Mustela erminea) and the least weasel (Mustela nivalis) (Elmeros 2006). Both species are known to prey on the Norwegian lemming (Lemmus lemmus) all year round (Ims and Fuglei 2005; King and Powell 2007) and have shown the time-lagging population growth necessary to cause regular 
population oscillations in lemmings (Korpimäki et al. 1991; Gilg et al. 2006). Nevertheless, the particular species-specific predation patterns remain unknown. Lemmings are key-stone species in the tundra ecosystem showing cyclic population patterns of 3-5 years (Hanski et al. 2001; Le Vaillant et al. 2018) and thus, the correct identification of mustelids, potentially able to destabilize rodent populations, is essential in understanding these dynamics.

Furthermore, weasels and stoats are also known to be rare, cryptic and elusive, forcing identification efforts to be based on camera trapping methods (Soininen et al. 2015) or indirect traces of their activity, such as tracks, hair or faeces (Pilot et al. 2007). Finding traces or knowing where to place traps is nevertheless difficult in areas such as the Fennoscandian tundra, due to its extent and lack of apparent hunting sites. To overcome this difficulty, this study focuses on the direct predator-prey interaction, using lemming winter nests predated by mustelids (MacLean et al. 1974; Duchesne et al. 2011) as a beacon to facilitate mustelid faecal sample collection (Feige et al. 2012). Lemming nests are easily identifiable in the tundra and predated nests can be distinguished from these based on the presence of fur lining the inner layer of the nests, as well as remains, such as scats and prey bones, left around the site (Sittler 1995). Since it is difficult to identify mustelid scats to species level through morphology alone (Hansen and Jacobsen 1999; Davison et al. 2002), in this study, species identification was achieved through DNA identification of faecal samples. This approach has been previously described in both methodological and fieldapplied studies (Riddle et al. 2003; Colli et al. 2005; Pilot et al. 2007; Rozhnov et al. 2008; Harrington et al. 2010; Monterroso et al. 2019). Therefore, considering that both species of mustelid have different life cycles (i.e. delayed embryo implantation in stoats and direct egg development in weasels (King 1983; Sheffield and King 1994; Hellstedt and Henttonen 2006)), it is essential to discern any different predation patterns amongst them.

Additionally, trophic niche segregation between the different sexes has been noted in many species (Forero et al. 2005; Mariano-Jelicich et al. 2008; Tucker et al. 2009; Guerao et al. 2011; Kernaléguen et al. 2015). Stoats and weasels, as many mustelids, are known to show evident sexual body size dimorphism (Moors 1980), which could lead to diverging trophic niches (Mcdonald et al. 2000; Purdey et al. 2004) or habitat use (Hellstedt and Henttonen 2006). Resource partitioning has been debated in these species, with some studies suggesting differences between sexes (King 1983; Sheffield and King 1994) and others not (Elmeros 2006; Piontek et al. 2015). In some studies, these species have even been considered as four functionally distinct morphospecies (Dayan and Simberloff 1994). Therefore, given the vast implications this could have on mustelid-lemming interactions, a sex determination protocol was also included to facilitate the comprehension of these cyclic dynamics.

Extended insights into the mustelid predation patterns on the tundra will supplement our understanding regarding the drivers of lemming cycles and the players in the specialist predator hypothesis. The purpose of the present study is to further establish the usage of DNA species identification of faecal samples as a highly accurate, non-invasive method, with successful applications in the field and a focus on predator-prey dynamics which can help improve conservation and management efforts in the tundra. The use of mustelidpredated lemming nests allows us to directly identify the predator to genus level (Mustela), facilitating sample collection in this environment. Moreover, the correct identification of predator species and sex will help unravel differences in their dynamics and thus facilitate the comprehension of mechanisms driving the regular oscillations of lemming populations in the Arctic. We expect the least weasel to cause the majority of predation events on lemming winter nests given their higher dependence on rodents and stronger numerical response (Sundell et al. 2013), while stoats have been known to more frequently prey on other species at lowrodent abundance (Korpimäki et al. 1991). Furthermore, we do not expect any sex-bias in lemming predation frequency in either mustelid species. We hypothesise that variations in lemming litter sizes could potentially balance out any differences in energetic requirements between sexes (Millar 2001) and that low abundance of larger prey would restrict preyswitching behaviour (Stoessel et al. 2019).

\section{Methods}

\section{Sampling and extraction}

Samples were exclusively obtained from the northern Swedish tundra, in the Vindelfällen Nature Reserve, Västerbotten county $\left(67^{\circ} 00^{\prime} \mathrm{N}, 17^{\circ} 00^{\prime} \mathrm{E}\right)$. Two sampling strategies were used in this study. 500-m lines were used in the years 2008 , 2012 and 2015, along 68, 72 and 93 transects, respectively (Menci 2015). Sampling in 2018, 2019 and 2020, was carried out along 12 wildlife triangular transects (Lindén 1996), with $4-\mathrm{km}$ sides ( $12 \mathrm{~km}$ in total). Moreover, the same triangular transects used in this study have already been used to survey wildlife populations in the past (Stoessel et al. 2019), further motivating our choice of placement. In either case, transects were distributed to cover the largest possible area of treeless tundra within the reserve and sampling was carried out in the month of July. Winter phases were classified as: low (winter between 2 years with decreased rodent density in summer), decrease (winter before a rodent density increase in summer) and increase (winter after a summer with increasing rodent density) following Stoessel 
et al. (2019). Summer lemming abundances were obtained from the National Environmental Monitoring Programme of Small Rodents (Ecke and Hörnfeldt 2019). The years 2008, 2012, 2015 and 2020 were all classified as decrease, while 2018 and 2019 were increase winters.

Faecal samples were obtained from mustelid-predated lemming nests (Sittler 1995), built in winter as a refuge from extreme temperatures and allowing them to breed (MacLean et al. 1974), which can be surveyed after snowmelt. Only nests created during the preceding winter were used. Lemming nests are known to persist for more than 1 year (Duchesne et al. 2011), however, old nests are easily distinguishable due to their bleached and partially decomposed appearance (MacLean et al. 1974). Predated nests were identified and recorded in the field, based on the presence of lemming fur lining the inner layers of the nests (Sittler 1995). Stoats and weasels are known to use lemming nests as wintering sites, leaving remains around the site, such as scats and prey bones (Sittler 1995). Encountered faeces were collected, placed in plastic bags and dried with silica pellets in the field. They were subsequently frozen and stored at $-20^{\circ} \mathrm{C}$ to minimize DNA decomposition and brought to the laboratory for further identification. Furthermore, opportunistic sample collection (i.e. outside transects) during the study years were also considered. The position of all samples found was recorded using a global positioning system receiver (Garmin eTrex).

Faecal samples collected in the field were processed in the laboratory through DNA extraction procedures, using the Qiagen QIAamp® Fast DNA Stool Mini Kit. The protocol as specified by the manufacturer was followed for all samples, including negative controls to monitor for crossover contamination. All extractions were done in a specialized low-quality-DNA pre-PCR laboratory to avoid contact with post-PCR products. Control tissue samples from stoat and weasel were extracted from skin using the Qiagen QIAamp ${ }^{\circledR}$ DNeasy Blood and Tissue Kit according to the manufacturer's instructions.

\section{PCR conditions}

The PCR reaction mix for amplification of the Cytochrome $b$ genes (producing a 400-bp fragment) contained about $50 \mathrm{ng}$ of DNA template, 13 pmol of each primer, $10 \times$ PCR buffer (Qiagen HotStarTaq ${ }^{\circledR}$ ), $2.5 \mathrm{mM} \mathrm{MgCl}{ }_{2}, 0.8 \mathrm{mM}$ dNTPs, $1.6 \mathrm{mg} \mathrm{mL}^{-1}$ of bovine serum albumin (BSA) and 1.5 units of Taq polymerase in a total volume of $25 \mu \mathrm{L}$. BSA and dNTPs were acquired from Thermo Scientific ${ }^{\mathrm{TM}}$, all other reagents used for this procedure were obtained from the Qiagen HotStarTaq ${ }^{\circledR}$ DNA Polymerase kit. The primers used for this procedure were; forward primer LRCB1 (Davison et al. 2002; Statham et al. 2005) and reverse primer H169498M (Statham et al. 2005). Reaction conditions differed slightly from those published by Statham et al. (2005), by running 45 cycles instead of 40. DNA fragments were visualized using a 1.5\% agarose gel electrophoresis and UV light to ensure suitable amplification.

\section{DNA sequencing}

Correctly amplified samples were purified and sequenced commercially at Macrogen Inc. () Europe (Amsterdam, Netherlands). This procedure was performed using the forward primer only (LRCB1). Chromatographs obtained from this procedure were visually controlled to discard low-quality sequences and then sequences were compared to those available at GenBank using the NCBI BLAST® tool.

\section{Sex determination}

Control samples of known sex were obtained from the Swedish Museum of Natural History in Stockholm to ensure correct identification of the study samples. The accession numbers were the following: 20005001, 20045270, 20095339 and 20175125. For this procedure, the SRY gene in the $Y$ chromosome was amplified, producing a 70-bp fragment for males, using Lut-SRY F and Lut-SRY R primers (Lynch and Brown 2006). The PCR mix for this amplification contained about $50 \mathrm{ng}$ of DNA template, $14 \mathrm{pmol}$ of each primer, $10 \times$ reaction buffer (Qiagen HotStarTaq®), $2.5 \mathrm{mM} \mathrm{MgCl}{ }_{2}$, $0.8 \mathrm{mM}$ dNTPs, $1.12 \mathrm{mg} \mathrm{mL}^{-1}$ of BSA and 4 units of Taq polymerase in a total volume of $25 \mu \mathrm{L}$. Reaction conditions were $95{ }^{\circ} \mathrm{C}$ for $10 \mathrm{~min}, 40$ cycles of $94{ }^{\circ} \mathrm{C}$ for $30 \mathrm{~s}, 60{ }^{\circ} \mathrm{C}$ for $30 \mathrm{~s}, 72{ }^{\circ} \mathrm{C}$ for $30 \mathrm{~s}$ and a final elongation of $72{ }^{\circ} \mathrm{C}$ for $10 \mathrm{~min}$. The DNA fragments were then observed through a $2 \%$ agarose gel electrophoresis and UV light to determine sex. This procedure was repeated twice to ensure correct sex determination of the samples. To discern between failed PCR products and female samples, the primers Lut-914F and Lut-914R (Dallas et al. 2000) were used alongside the previous ones to visualize a 150-bp fragment on the female samples. The mix used in the PCR was: 50 ng of DNA template, 14 pmol of each primer, $10 \times$ reaction buffer (Qiagen HotStarTaq $\left.{ }^{\circledR}\right), 2.5 \mathrm{mM} \mathrm{MgCl}_{2}, 0.8 \mathrm{mM}$ dNTPs, $1.12 \mathrm{mg} \mathrm{mL}^{-1}$ of BSA and 2.5 units of Taq polymerase in a total volume of $25 \mu \mathrm{L}$. The PCR and electrophoresis conditions remained the same as above.

\section{Statistical analysis}

Due to limited sample sizes, binomial tests were conducted to show any significant differences between species (i.e. stoats and weasels) and sex (i.e. weasel males vs. females) in the total material. Statistical analyses were performed using R CRAN project (R Development Core Team 2020). 
Successfully identified mustelid scats were classified according to year of sample collection and related to winter phase of the lemming cycle.

\section{Results}

\section{Species determination}

DNA was successfully amplified for 92 of 114 faecal samples ( $80.7 \%$ success rate) (Table 1). Of the successfully identified samples, 76 were identified as least weasels (82.6\%), nine as stoats $(9.8 \%)$ and the remaining seven samples were surprisingly identified as Arctic fox (7.6\%). To exclude DNA contamination as a possible cause for fox presence, the samples were later morphologically inspected and identified as fox scats. Their presence in our study could be attributed to errors by surveyors mistakenly collecting fox scat samples (Harrington et al. 2010) where no mustelid predation had taken place. Weasel scats were found to be more abundant regardless of lemming population densities, both during decrease and increase phases (Table 1), except in years with low successful sample size (2018 and 2020). A binomial test proved that there was a clear significant difference between samples identified as weasels compared to stoats $(p<0.0001)$.

\section{Sex determination}

All species-identified mustelid samples underwent sex determination, with a success rate of $95.3 \%$ (Table 1); three samples belonging to stoats were females and four were males, whilst 39 weasel samples belonged to males (frequency:
$0.53 ; 95 \%$ CI $0.41-0.64$ ) and 35 to females (frequency: 0.47 ; 95\% CI 0.36-0.59). Scats identified as weasels were analysed using a binomial test which showed no differences in sex frequencies $(p=0.73)$. Sex ratios in least weasel scats across all sampled years (0.90), showed no clear sex-bias when predating on lemmings. Nevertheless, given the low sample size of stoats, no clear conclusions regarding any differences between sexes can be drawn for this particular species.

\section{Discussion}

The role of mustelids as specialist predators driving the lemming cycle has been discussed since the onset of the research on the rodent cycle (Elton 1924). In this study, least weasels rather than stoats, seemed to be responsible for the majority of mustelid-related predation on wintering lemming nests (Table 1). This is in accordance with previous observations, where it has been proposed that weasels show more rodent-specialist behaviours in predation (Mcdonald et al. 2000; Hellstedt et al. 2006; Feige et al. 2012). On the other hand, stoats seem to switch prey at low primary prey densities (Korpimäki et al. 1991; Elmeros 2006) and have been shown to not find this species of lemming particularly palatable (Storbråten 1998). Stoats have also been shown to prefer lush, richer habitats (Oksanen et al. 1992), displacing weasels to poorer habitats with lower prey abundance (Erlinge and Sandell 1988), such as the more barren tundra. Further, samples analysed in this study cover 6 years of data including different winter phases in the lemming cycle (Table 1), so that different prey population densities were accounted for. Nevertheless, decrease years were

Table 1 Results obtained from successfully identified samples to species and sex level according to year (phase) and transect type

\begin{tabular}{|c|c|c|c|c|c|c|c|}
\hline Year (phase) & Transect type & Sample size & $\begin{array}{l}\text { Successful } \\
\text { samples (\%) }\end{array}$ & Identified species (\%) & Males & Females & Female ratio \\
\hline 2008 (decrease) & $500 \mathrm{~m}$ line & 22 & $17(77.3 \%)$ & M. nivalis (100\%) & 9 & 8 & 0.47 \\
\hline \multirow[t]{3}{*}{2012 (decrease) } & $500 \mathrm{~m}$ line & 24 & $18(75.0 \%)$ & M. nivalis $(83.3 \%)$ & 10 & 5 & 0.33 \\
\hline & & & & M. erminea $(5.6 \%)$ & 0 & 1 & 1.00 \\
\hline & & & & V. lagopus (11.1\%) & - & - & - \\
\hline \multirow[t]{3}{*}{2015 (decrease) } & $500 \mathrm{~m}$ line & 51 & $46(90.2 \%)$ & M. nivalis $(82.6 \%)$ & 18 & 20 & 0.53 \\
\hline & & & & M. erminea $(8.7 \%)$ & 2 & 2 & 0.50 \\
\hline & & & & V. lagopus $(8.7 \%)$ & - & - & - \\
\hline \multirow[t]{2}{*}{2018 (increase) } & $12 \mathrm{~km}$ triangle & 3 & $2(66.7 \%)$ & M. erminea $(50.0 \%)$ & 1 & 0 & 0.00 \\
\hline & & & & V. lagopus (50.0\%) & - & - & - \\
\hline \multirow[t]{2}{*}{2019 (increase) } & $12 \mathrm{~km}$ triangle & 10 & $7(70.0 \%)$ & M. erminea $(14.3 \%)$ & - & - & - \\
\hline & & & & M. nivalis $(85.7 \%)$ & 2 & 2 & 0.50 \\
\hline 2020 (decrease) & $12 \mathrm{~km}$ triangle & 4 & $2(50.0 \%)$ & M. erminea (100\%) & 1 & 0 & 0.00 \\
\hline Total samples & & 114 & $92(80.7 \%)$ & & & & \\
\hline
\end{tabular}

Note that sexual determination was only performed in mustelid-identified samples (i.e. not in V. lagopus) and was not successful for all samples 
more abundant (2008, 2012, 2015 and 2020), which should result in higher frequencies of stoat counts, considering their stronger time-lag due to delayed embryo implantation (Sheffield and King 1994). This, however, was not the case in the majority of years, indicating that the weasel is responsible for the majority of mustelid predation occurrences on winter nests in this area.

Low sample sizes due to decreased nest counts in 2018, 2019 and 2020 might bias any conclusions drawn from specific phases, therefore an overall analysis is more suitable in this study. Nevertheless, stoat frequency seems to have increased during those years, while weasel predation occurrences have decreased (Table 1). Lemming population oscillations in the area also seem to have dampened during these years (Ecke and Hörnfeldt 2019). Therefore, and considering the aforementioned predator hypothesis, these findings suggest that weasel presence in the Swedish tundra could be a destabilizing factor causing cyclic populations in lemmings. Nonetheless, it is important to note that interspecific differences in marking behaviour (i.e. whether deposition of scats is in close proximity to predated nests) may cause a bias in faecal sample collection, as could be the case in otters (Hutchings and White 2000; Kruuk 2006). From our findings, it was clear that both species show these behaviours, however the frequency of occurrence remains unknown. To further investigate the specificity of mustelid predation, it would therefore be necessary to complement this approach by analysing stomach contents of caught weasels and stoats, which, given its invasive approach, would entail many logistical and ethical implications. It is nevertheless clear that correct DNA identification of predation remains in this area is critical in understanding predator-prey dynamics, since two morphologically similar species were found to predate on lemmings.

In this regard, mustelid identification was successfully achieved for a large proportion of samples (Table 1), further solidifying the use of non-invasive faecal DNA analysis already established in other studies (Gómez-Moliner et al. 2004; Statham et al. 2005; Rozhnov et al. 2008; Harrington et al. 2010). This high success rate can be attributed in part to low DNA degradation due to the climatic conditions encountered in the field, with mean summer and winter temperatures ranging from 9 to $-5^{\circ} \mathrm{C}$, respectively, over the decade (https://www.smhi.se/data/meteorologi/tempe ratur). This would allow for suitable preservation of faecal DNA until late June and early July, when samples were collected. DNA is known to rapidly degrade when subject to adverse weather conditions, such as prolonged exposure to UV radiation or rainfall (Davison et al. 2002; Harrington et al. 2010) and low-quality DNA is strongly correlated to scat freshness (Nsubuga et al. 2004; Hájková et al. 2006; Sittenthaler et al. 2020). We therefore attribute the non-successful amplification to these factors. Furthermore, the use of predator-specific primers in the amplification procedure excluded any potential prey DNA from interfering with the desired PCR product (Murakami 2002).

Genetic identification can also allow for further insights about predation patterns, such as the relative importance of males and females as lemming predators. The applicability of the sex determination protocol also gave satisfactory results, with $95.3 \%$ of samples being successfully sexed (Table 1). Given that all samples used for sexual identification had already undergone species identification, and were therefore known to have amplifiable DNA, these results are not surprising. Sex determination through the analysis of faecal remains has been used in mammal populations in previous studies (Ralls et al. 2010; Pelizzon et al. 2017; Arandjelovic and Vigilant 2018) and a similar protocol has been shown to be an accurate method of sex identification in mustelids (Dallas et al. 2000; Lynch and Brown 2006; Statham et al. 2007; Horecka 2018). Our results therefore suggest that there is no apparent trophic segregation by sex in the least weasel, in regards to lemming winter nest predation, which is in accordance with previous investigations (Elmeros 2006; Piontek et al. 2015). Different energetic requirements between sexes, due to body size dimorphism in weasels could be satisfied by varying lemming litter size (Millar 2001). Furthermore, the low abundance of larger alternative prey, such as lagomorphs or larger voles (Stoessel et al. 2019), especially in winter (Sheffield and King 1994), restrict trophic segregation options. Sample size was not large enough to reach any conclusion concerning sex differences in stoats. Moreover, the genetic markers used in this paper do not provide individual resolution, therefore, future efforts should design a sampling and analytic protocol with individual resolution to assess predation patterns in relation to the actual abundance of weasels and stoats, as well as individual variation in predation patterns.

In conclusion, our results show that the least weasel seems to be responsible for the majority of predated nests in the tundra, which, together with its known specificity could have large implications in the predator hypothesis for lemming cycles. There were also no apparent sex differences in lemming predation for this species. We have shown that DNA analysis of faeces could be a useful tool in the clarification of the mechanisms driving the lemming cycle. We would like to stress the importance of secondary supplemental methods including camera traps and hair identification (Teerink 2003), used in parallel to DNA identification, to reliably monitor populations of such elusive predatory species and further elucidate on such controversial dynamics.

Acknowledgements We thank Birgith Unterthurner, Camille Garcera, Marianne Stoessel and the many volunteers and students that helped in the collection of samples throughout the years. We would also like to thank Daniela Kalthoff from the Natural History Museum of Stockholm, for providing us with tissue samples. We are grateful to editor 
Dieter Piepenburg, Heikki Henttonen, Nigel Yoccoz and an anonymous reviewer for improving the manuscript quality.

Author contributions $\mathrm{JV}, \mathrm{KN}$ and $\mathrm{AA}$ conceived and designed research. JV, SM, CW and MLV conducted experiments, collected and analysed data. JV wrote the manuscript, with comments from coauthors. All authors read and approved the manuscript.

Funding Open access funding provided by Stockholm University. This study was funded by the Oscar and Lili Lamm Memorial Foundation (FO2018-0022) and the Wildlife Management Fund (802-0199-18) by the Swedish Environmental Protection Agency to KN. Göran Gustafsson Foundation for the Nature in Lapland, Stockholm University EcoClim Project, Fjällräven International AB (Grant No. 1053023), and Naturkompaniet AB (Grant No. 2053001) to AA.

Data availability NA.

Code availability NA.

\section{Declarations}

Conflict of interest The authors declare that they have no conflict of interest.

Ethical approval Ethics approval not needed. Field work in Vindelfjällen nature reserve was carried out with specific approval from the County Administration Board (521-3191-2014 and 521-4640-2019).

Consent to participate All authors have given consent to participate.

Consent for publication All authors have given consent for publication.

Open Access This article is licensed under a Creative Commons Attribution 4.0 International License, which permits use, sharing, adaptation, distribution and reproduction in any medium or format, as long as you give appropriate credit to the original author(s) and the source, provide a link to the Creative Commons licence, and indicate if changes were made. The images or other third party material in this article are included in the article's Creative Commons licence, unless indicated otherwise in a credit line to the material. If material is not included in the article's Creative Commons licence and your intended use is not permitted by statutory regulation or exceeds the permitted use, you will need to obtain permission directly from the copyright holder. To view a copy of this licence, visit http://creativecommons.org/licenses/by/4.0/.

\section{References}

Andersson M, Erlinge S (1977) Influence of predation on rodent populations. Oikos 29:591-597. https://doi.org/10.2307/3543597

Andreassen HP, Sundell J, Ecke F et al (2021) Population cycles and outbreaks of small rodents: ten essential questions we still need to solve. Oecologia 195:601-622. https://doi.org/10.1007/ s00442-020-04810-w

Arandjelovic M, Vigilant L (2018) Non-invasive genetic censusing and monitoring of primate populations. Am J Primatol 80:1-14. https://doi.org/10.1002/ajp.22743

Boonstra R, Boag PT (1992) Spring declines in Microtus pennsylvanicus and the role of steroid hormones. J Anim Ecol 61:339. https:// doi.org/10.2307/5326
Colli L, Cannas R, Deiana AM et al (2005) Identification of mustelids (Carnivora: Mustelidae) by mitochondrial DNA markers. Mamm Biol 70:384-389. https://doi.org/10.1016/j.mambio.2005.02.005

Dallas JF, Carss DN, Marshall F et al (2000) Sex identification of the Eurasian otter Lutra lutra by PCR typing of spraints. Conserv Genet 1:181-183

Davison A, Birks JDS, Brookes RC et al (2002) On the origin of faeces: morphological versus molecular methods for surveying rare carnivores from their scats. J Zool 257:141-143. https://doi.org/ $10.1017 / \mathrm{S} 0952836902000730$

Dayan T, Simberloff D (1994) Character displacement, sexual dimprphism, and morphological variation among British and Irish mustelids. Ecology 75:1063-1073. https://doi.org/10.2307/1939430

Duchesne D, Gauthier G, Berteaux D (2011) Habitat selection, reproduction and predation of wintering lemmings in the Arctic. Oecologia 167:967-980. https://doi.org/10.1007/s00442-011-2045-6

Ecke F, Hörnfeldt B (2019) Miljöövervakning av smågnagare. Retrieved October 25, 2020, from http://www.slu.se/mo-smagn agare

Ekerholm P, Oksanen L, Oksanen T, Schneider MF (2004) The impact of short-term predator removal on vole dynamics in an arctic-alpine landscape. Oikos 106:457-468

Elmeros M (2006) Food habits of stoats Mustela erminea and weasels Mustela nivalis in Denmark. Acta Theriol (warsz) 51:179_ 186. https://doi.org/10.1007/BF03192669

Elton CS (1924) Periodic fluctuations in the numbers of animals: their causes and effects. Br J Exp Biol 2:119-163

Erlinge S, Sandell M (1988) Coexistence of stoat, Mustela erminea, and weasel, $M$. nivalis: social dominance, scent communication, and reciprocal distribution. Oikos 53:242-246

Fauteux D, Gauthier G, Berteaux D (2016) Top-down limitation of lemmings revealed by experimental reduction of predators. Ecology 97:3231-3241. https://doi.org/10.1002/ecy.1570

Feige N, Ehrich D, Popov IY, Broekhuizen S (2012) Monitoring least weasels after a winter peak of lemmings in taimyr: body condition, diet and habitat use. Arctic 65:273-282. https://doi. org/10.14430/arctic4215

Forbes KM, Stuart P, Mappes T et al (2014) Food resources and intestinal parasites as limiting factors for boreal vole populations during winter. Ecology 95:3139-3148. https://doi.org/10. 1890/13-2381.1

Forero MGM, González-Solís J, Hobson KAK et al (2005) Stable isotopes reveal trophic segregation by sex and age in the southern giant petrel in two different food webs. Mar Ecol Prog Ser 296:107-113. https://doi.org/10.3354/meps296107

Gilg O, Hanski I, Sittler B (2003) Cyclic dynamics in a simple vertebrate predator-prey community. Science 302:866-868. https://doi. org/10.1126/science. 1087509

Gilg O, Sittler B, Sabard B et al (2006) Functional and numerical responses of four lemming predators in high arctic Greenland. Oikos 113:193-216. https://doi.org/10.1111/j.2006.0030-1299. 14125.x

Gómez-Moliner BJ, Cabria MT, Rubines J et al (2004) PCR-RFLP identification of mustelid species: European mink (Mustela lutreola), American mink (M. vison) and polecat (M. putorius) by analysis of excremental DNA. J Zool 262:311-316. https://doi. org/10.1017/S0952836903004667

Graham IM, Lambin X (2002) The impact of weasel predation on cyclic field-vole survival: the specialist predator hypothesis contradicted. J Anim Ecol 71:946-956. https://doi.org/10.1046/j. 1365-2656.2002.00657.x

Guerao G, Rotllant G, Gisbert E et al (2011) Consistent habitat segregation between sexes in the spider crabs Maja brachydactyla and Maja squinado (Brachyura), as revealed by stable isotopes. Sci Mar 80:103-110. https://doi.org/10.3989/scimar.04236.23B 
Hájková P, Zemanová B, Bryja J et al (2006) Factors affecting success of PCR amplification of microsatellite loci from otter faeces. Mol Ecol Notes 6:559-562. https://doi.org/10.1111/j.1471-8286.2006. 01269.x

Hansen MM, Jacobsen L (1999) Identification of mustelid species: Otter (Lutra lutra), American mink (Mustela vison) and polecat (Mustela putorius), by analysis of DNA from faecal samples. J Zool 247:177-181. https://doi.org/10.1017/S0952836999002058

Hanski I, Hansson L, Henttonen H (1991) Specialist predators, generalist predators, and the microtine rodent cycle. J Anim Ecol 60:353. https://doi.org/10.2307/5465

Hanski I, Henttonen H, Korpimäki E et al (2001) Small-rodent dynamics and predation. Ecology 82:1505-1520. https://doi.org/10. 1890/0012-9658(2001)082[1505:SRDAP]2.0.CO;2

Harrington LA, Harrington AL, Hughes J et al (2010) The accuracy of scat identification in distribution surveys: American mink, Neovison vison, in the northern highlands of Scotland. Eur J Wildl Res 56:377-384. https://doi.org/10.1007/s10344-009-0328-6

Hellstedt P, Henttonen H (2006) Home range, habitat choice and activity of stoats (Mustela erminea) in a subarctic area. $\mathrm{J}$ Zool 269:205-212. https://doi.org/10.1111/j.1469-7998.2006. 00072.x

Hellstedt P, Sundell J, Helle P, Henttonen H (2006) Large-scale spatial and temporal patterns in population dynamics of the stoat, Mustela erminea, and the least weasel, M. nivalis, in Finland. Oikos 115:286-298. https://doi.org/10.1111/j.2006.0030-1299.14330.x

Horecka B (2018) Usefulness of a modified system of molecular sex identification in Mustelidae including museum specimens. Ann Zool Fenn 55:151-158. https://doi.org/10.5735/086.055.0602

Hoset KS, Kyrö K, Oksanen T et al (2014) Spatial variation in vegetation damage relative to primary productivity, small rodent abundance and predation. Ecography (cop) 37:894-901. https://doi. org/10.1111/ecog.00791

Hutchings MR, White PCL (2000) Mustelid scent-marking in managed ecosystems: implications for population management. Mamm Rev 30:157-169. https://doi.org/10.1046/j.1365-2907.2000.00065.x

Ims RA, Fuglei E (2005) Trophic interaction cycles in tundra ecosystems and the impact of climate change. Bioscience 55:311. https:// doi.org/10.1641/0006-3568(2005)055[0311:TICITE]2.0.CO;2

Kernaléguen L, Cherel Y, Knox TC et al (2015) Sexual niche segregation and gender- specific individual specialisation in a highly dimorphic marine mammal. PLoS ONE 10:1-16. https://doi.org/ 10.1371/journal.pone.0133018

King CM (1983) Mustela erminea. Mamm Species. https://doi.org/ $10.2307 / 3503967$

King CM, Powell RA (2007) The natural history of weasels and stoats: ecology, behavior, and management. Oxford University Press, Oxford

Korpimäki E, Norrdahl K, Rinta-Jaskari T (1991) Responses of stoats and least weasels to fluctuating food abundances: is the low phase of the vole cycle due to mustelid predation? Oecologia 88:552561. https://doi.org/10.1007/BF00317719

Krebs CJ (2011) Of lemmings and snowshoe hares: the ecology of northern Canada. Proc R Soc B 278:481-489. https://doi.org/10. 1098/rspb.2010.1992

Krebs CJ (2013) Population fluctuations in rodents. University of Chicago Press, Chicago

Kruuk H (2006) Otters: ecology, behaviour and conservation. Oxford University Press, Oxford

Le Vaillant M, Erlandsson R, Elmhagen B et al (2018) Spatial distribution in Norwegian lemming Lemmus lemmus in relation to the phase of the cycle. Polar Biol 41:1391-1403. https://doi.org/10. 1007/s00300-018-2293-6

Legagneux P, Gauthier G, Berteaux D et al (2012) Disentangling trophic relationships in a High Arctic tundra ecosystem through food web modeling. Ecology 93:1707-1716. https://doi.org/10. 1890/11-1973.1

Lindén H (1996) Wildlife triangle scheme in Finland: methods and aims for monitoring wildlife populations. Finn Game Res 49:4-11

Lynch ÁB, Brown MJFF (2006) Molecular sexing of pine marten (Martes martes): how many replicates? Mol Ecol Notes 6:631633. https://doi.org/10.1111/j.1471-8286.2006.01386.x

MacLean SF, Fitzgerald BM, Pitelka FA (1974) Population cycles in Arctic lemmings: winter reproduction and predation by weasels. Arct Alp Res 6:1. https://doi.org/10.2307/1550365

Mariano-Jelicich R, Botto F, Martinetto P et al (2008) Trophic segregation between sexes in the Black Skimmer revealed through the analysis of stable isotopes. Mar Biol 155:443-450. https://doi.org/ 10.1007/s00227-008-1042-8

Mcdonald RA, Webbon C, Harris S (2000) The diet of stoats (Mustela erminea) and weasels (Mustela nivalis) in Great Britain. J Zool 252:363-371. https://doi.org/10.1017/S0952836900000108

Menci S (2015) Analysis of the impact of mustelid predation on Norwegian lemming (L. lemmus) populations in the tundra landscape of northern Sweden, using molecular methods. MSc Thesis, Stockholm University, Stockholm

Millar JS (2001) On reproduction in lemmings. Ecoscience 8:145-150. https://doi.org/10.1080/11956860.2001.11682639

Monterroso P, Godinho R, Oliveira T et al (2019) Feeding ecological knowledge: the underutilised power of faecal DNA approaches for carnivore diet analysis. Mamm Rev 49:97-112. https://doi. org/10.1111/mam.12144

Moors PJ (1980) Sexual dimorphism in the body size of mustelids (Carnivora): the roles of food habits and breeding systems. Oikos 34:147-158. https://doi.org/10.2307/3544175

Murakami T (2002) Species identification of mustelids by comparing partial sequences on mitochondrial DNA from fecal samples. J Vet Med Sci 64:321-323. https://doi.org/10.1292/jvms.64.321

Nsubuga AM, Robbins MM, Roeder AD et al (2004) Factors affecting the amount of genomic DNA extracted from ape faeces and the identification of an improved sample storage method. Mol Ecol 13:2089-2094. https://doi.org/10.1111/j.1365-294X.2004. 02207.x

Oksanen T, Oksanen L, Norberg M (1992) Habitat use of small mustelids in north Fennoscandian tundra: a test of the hypothesis of patchy exploitation ecosystems. Ecography (cop) 15:237-244. https://doi.org/10.1111/j.1600-0587.1992.tb00030.x

Pelizzon C, da Silva CC, Caballero S et al (2017) Sex identification of the extant mega mammal, the lowland tapir, Tapirus terrestris (Tapiridae, Mammalia), by means of molecular markers: new outlook for non-invasive samples. Conserv Genet Resour 9:17-19. https://doi.org/10.1007/s12686-016-0607-y

Pilot M, Gralak B, Goszczynski J, Posłuszny M (2007) A method of genetic identification of pine marten (Martes martes) and stone marten (Martes foina) and its application to faecal samples. J Zool 271:140-147. https://doi.org/10.1111/j.1469-7998.2006.00179.x

Piontek AM, Wierzbowska IA, Bevanger K, Tokarz WM (2015) Comparison of the diet of stoat (Mustela erminea) in relation to sex and season in Norway. Mamm Res 60:301-307. https://doi.org/ 10.1007/s13364-015-0237-x

Purdey DC, King CM, Lawrence B (2004) Age structure, dispersion and diet of a population of stoats (Mustela erminea) in southern Fiordland during the decline phase of the beech mast cycle. $\mathrm{N}$ Z J Zool 31:205-225. https://doi.org/10.1080/03014223.2004. 9518373

R Development Core Team (2020) R: a language and environment for statistical computing. Vienna, Austria. https://www.R-project.org/

Ralls K, Sharma S, Smith DA et al (2010) Changes in kit fox defecation patterns during the reproductive season: implications for noninvasive surveys. J Wildl Manage 74:1457-1462. https://doi.org/ $10.2193 / 2009-401$ 
Reid DG, Krebs CJ, Kenney AJ (1997) Patterns of predation on noncyclic lemmings. Ecol Monogr 67:89-108. https://doi.org/10. 1890/0012-9615(1997)067[0089:POPONL]2.0.CO;2

Riddle AE, Pilgrim KL, Mills LS et al (2003) Identification of mustelids using mitochondrial DNA and non-invasive sampling. Conserv Genet 4:241-243. https://doi.org/10.1023/A:1023338622905

Rozhnov V, Morgulis A, Kholodova M, Meshcherskii I (2008) The use of molecular genetic methods for identification of mustelid species by analyzing feces. Russ J Ecol 39:70-72. https://doi.org/ $10.1134 / \mathrm{s} 1067413608010128$

Sheffield SR, King CM (1994) Mustela nivalis. Mamm Species. https:// doi.org/10.2307/3504183

Sittenthaler M, Schöll EM, Leeb C et al (2020) Marking behaviour and census of Eurasian otters (Lutra lutra) in riverine habitats: what can scat abundances and non-invasive genetic sampling tell us about otter numbers? Mamm Res 65:191-202. https://doi.org/10. 1007/s13364-020-00486-y

Sittler B (1995) Response of stoats (Mustela erminea) to a fluctuating lemming (Dicrostonyx groenlandicus) population in North East Greenland: preliminary results from a long term study. Ann Zool Fenn 32:79-92

Soininen EM, Jensvoll I, Killengreen ST, Ims RA (2015) Under the snow: a new camera trap opens the white box of subnivean ecology. Remote Sens Ecol Conserv 1:29-38. https://doi.org/10.1002/rse2.2

Statham MJ, Turner PD, O'Reilly C (2005) Use of PCR amplification and restriction enzyme digestion of mitochondrial D-loop for identification of mustelids in Ireland. Irish Nat J 28:1-6
Statham MJ, Turner PD, O'Reilly C (2007) Molecular sex identification of five mustelid species. Zool Stud 46:600-608

Stoessel M, Elmhagen B, Vinka M et al (2019) The fluctuating world of a tundra predator guild: bottom-up constraints overrule topdown species interactions in winter. Ecography (cop) 42:488-499. https://doi.org/10.1111/ecog.03984

Storbråten GK (1998) Distribution, food selection and behaviour of stoat Mustela erminea $\mathrm{L}$. in a period of declining densities of small rodents. Candidate scientist, University of Bergen, Bergen

Sundell J, O'Hara RB, Helle P et al (2013) Numerical response of small mustelids to vole abundance: delayed or not? Oikos 122:11121120. https://doi.org/10.1111/j.1600-0706.2012.00233.x

Teerink BJ (2003) Hair of west European mammals: atlas and identification key. Cambridge University Press, Cambridge

Tucker S, Bowen WD, Iverson SJ et al (2009) Sources of variation in diets of harp and hooded seals estimated from quantitative fatty acid signature analysis (QFASA). Mar Ecol Prog Ser 384:287302. https://doi.org/10.3354/meps08000

Turchin PD, Oksanen L, Ekerholm P et al (2000) Are lemmings prey o predators? Nature 405:562-565

Publisher's Note Springer Nature remains neutral with regard to jurisdictional claims in published maps and institutional affiliations. 